\title{
The urban governance of asylum as a "battleground": policies of exclusion and efforts of inclusion in Italian towns
}

Maurizio Ambrosini, university of Milan

The governance of immigration has been increasingly discussed, especially in Europe, as a multilevel and multi-actor process in which diverse institutional and non-institutional subjects play a role (Scholten et al., 2018). In particular the efforts by national governments to achieve more control over migration flows involve local governments more directly than in the past (Guiraudon and Lahav 2000; Oomen and Lenders 2020).

This trend encompasses a contradiction in which local policies in Europe have often been considered, at least in the last two decades, more open than national policies, more oriented towards a pragmatic reception of immigrants and to the admission to local services also of immigrants with legally dubious or irregular status. In the US, “sanctuary cities", such as New York or San Francisco, have resisted federal policies against unauthorized immigration. They have avoided raids and granted some social services also to immigrants without legal status (Oomen, Davis and Grigolo, 2016). In the UK, the "City of Sanctuary" movement was established in Sheffield in 2005, and in 2016 it had groups operating in more than 80 towns, cities and villages (Bauder, 2017). While sanctuary movements are also crucial sites for defending immigrants against the U.S. Federal government's policies and practices, studies in the U.S. (and in Canada as well) have identified local powers committed to combatting irregular immigration with greater determination than federal powers (Chand and Schreckhise, 2014; Varsanyi 2008; Gilbert 2009). In the EU, local policies of exclusion have not received much attention in the academic debate, whereas positive aspects of local policies have been more often studied (CLIP Network, 2010; Hillmann 2019; Penninx et al., 2004). An exception is the literature on border towns, camps and detention centres in which local authorities are often involved (Agier 2008; Mankou 2013; Ferrer-Gallardo and Albet-Mas 2016). Northern Italy, however, has 
supplied research on local policies of exclusion with many examples (Lebuhn 2013; Mantovan and Ostanel, 2015; Semprebon, 2011).

This article analyses the local governance of asylum from the perspective of a "battleground". On the one hand, it considers the different attitudes of Italian municipalities to asylum seekers, and in particular the mobilization of local governments against refugees' reception. On the other hand, it shows how civil society actors mobilize in favour of the reception of refugees and immigrants with dubious legal status, or against them. It suggests that not only at the national or EU boundaries, but also at a local level, a complex "borderwork" (Rumford 2006) occurs. It involves not only public powers but also a wide range of other actors: international humanitarian agencies; NGOs and civil society organizations; public administrations and local authorities; private citizens and local societies (Fontanari and Borri, 2017: 33).

This "battleground" consequently involves diverse actors. Beyond the idea of a "negotiated order" as the result of the interaction among actors (mainly institutional) in the multilevel governance framework (Alcantara and Nelles 2014), the management of asylum at a local level is the output of conflict and cooperation, of alternative views and political actions, of official policies and practical help, of formal statements and informal practices. On this 'battleground', the positions assumed by the actors on the asylum and immigration issue are crucial for asserting their cultural and political identities, and at the same time in raising awareness and shaping this identity more precisely in relation to, and often in contrast with, the positions of other actors.

Exploring the features of the "battleground" further, the article later focuses in particular on "supporters" acting in favour of asylum seekers in various ways, for moral, political or religious reasons. I am particularly interested in the political significance of supporting refugees. To recap, the practical governance of immigration and asylum is not only determined at an institutional level; it is also influenced by this mobilization on the part of civil society.

The article is structured as follows. The first section briefly describes figures and policies on asylum in Italy. The second section explains in more detail how the reception policy works in practice, while 
the third section highlights the role of local authorities, and in particular the opposition against the establishment of reception centres for asylum seekers. Section 4 instead illustrates the actions conducted by various civil society actors in favour of asylum seekers and refugees. Section 5 discusses the political meaning of these activities. Section 6 presents the conclusions.

\section{Asylum seekers in Italy}

It is first necessary to understand the so-called "refugee crisis" in Italy as a crisis of policies of reception, more than a crisis deriving from the numbers of asylum seekers.

Contrary to what is believed, Italy's maritime borders were never the main entry points to the country for foreign immigrants (Ambrosini 2018). It is true that already in the '90 and in the '00, but especially from 2011 onwards Italy has become a destination for asylum seekers and other migrants coming from the Southern coast of the Mediterranean Sea, in particular through the so-called 'central corridor' from Libya (Caselli 2019; D’Angelo 2019). In public opinion, the terms 'immigrants', "landed people" and 'asylum seekers' have started to be used interchangeably, and the dominant perception has become that of Italy as a country 'under invasion' by unwanted immigrants (Bruno 2016; Dimitriadis 2019). It can be seen as an example of the "gap between evidence and politics" (Baldwin-Edwards, Blitz and Crawley 2019: 2147).

As a matter of fact, not only was the number of landings less than imagined, but most of the migrants who entered from the sea until 2015 preferred to continue their journey towards Northern Europe by crossing the Alps. Thus, the implicit role of Italy was that of a bridge, favouring their passage and not strongly enforcing the Dublin III rules on asylum seekers' identification at the arrival point. Only a minority of people landing in Italy claimed asylum in the country, so that there was a gap between the number of landings in Italy and that of applications for asylum (Marchetti 2020a).

In 2015, in reaction to the so-called "migration crisis", the Italian government was obliged by the EU partners, through the European Agenda on Migration, to set up so-called "hotspots" on Italian territory and also to ensure that the identification of asylum seekers was secured instantly (by taking 
fingerprints for example) (Ansems de Vries and Guild 2019). The European Agenda on Migration of 2015 (European Commission 2015) also envisaged the resettlement of asylum seekers in other countries, fixing precise national quotas. The national governments of other EU countries, however, explicitly or implicitly, rejected enforcement of that agreement, or its application was slowed down. Only about 13,000 asylum seekers were relocated, and in the end the project was abandoned, highlighting the difficulties of managing the issue of asylum in democratic states (Sciortino 2019). From a (mainly) transit country, Italy was transformed into a (mainly) destination country for asylum seekers. It has become the responsible of their reception and, in case, social integration.

Consequently, the rate of applications for asylum in Italy on the total number of landings has rapidly increased. It rose from 37 per cent in 2014 to 56 per cent in 2015, to 68 per cent in 2016. In 2017, it surpassed 100 per cent, because of arrivals by land across North-Eastern borders and rejections of people to Italy as the first country of arrival, in accordance with the Dublin conventions.

Thereafter, the number of asylum seekers hosted in Italy grew until July 2017 (Fig. 1): 340,323 between 2015 and 2017, compared to 241,752 in the previous decade (2005-2014) (Marchetti 2020b). In response to this challenge, the government (centre-left coalition, headed by Gentiloni, with Minniti Minister of Home Affairs) signed in February 2017 a Memorandum of Agreement with the Libyan government and local forces, which came into force in July, and began to hinder the operations of search and rescue by NGO ships. The consequence was a sharp reduction of new inflows from the Libyan coasts. Most asylum seekers were blocked or intercepted by the Libyan navy and held in detention centres, where there was a stark absence of international control: a point already raised some years ago by Gammeltoft-Hansen T. and N. Nyberg Sørensen (2013).

At the end of 2017, the number of asylum seekers dropped to 119,310 (Fig.1). In 2018 the first Conte government (Five Stars Movement and League ${ }^{1}$, with Salvini, League, minister of Home Affairs)

\footnotetext{
${ }^{1}$ The League (in Italian: Lega, previously "Lega Nord", i.e. "Northern League") was the winner of the last elections for the European Parliament in Italy (May 2019). It takes an open anti-immigrants and anti-refugees stance. In the past it asserted the reasons of the (richer) Northern Italian regions against the central government and the (poorer) Southern regions. But in recent years it has changed its name (from Lega Nord to Lega) and assumed a nationalistic attitude, taking
} 
from the outset adopted a hostile attitude towards asylum seekers, immigrants, and NGOs rescuing people in the Mediterranean. Accordingly, the number of people arriving by sea dropped dramatically in 2018: 23,370, less than in Spain or Greece.

(figure 1 here)

A crucial point of the new approach was the approval, on 1 December 2018, of law no.132/2018 by the first Conte government: this law modified the reception system in a more restrictive direction. According to this law, reception centres ${ }^{2}$ should furnish asylum seekers with just "bed, bath and bread", while the other services (such as legal help, psychological and medical assistance, Italian lessons, and orientation to the labour market) are no longer funded.

\section{The reception policy}

In theory, the pillar of the reception policy until December 2018 was the SPRAR system, established in 2003 and renamed SIPROIMI at the end of 2018: a response to asylum based on the cooperation between the national government and local authorities, which are required to apply to manage a reception facility. The latter hosts in principle a small number of asylum seekers, providing various services in cooperation with the third sector: not only bed, bath and bread, but also Italian language courses, orientation to the local labour market and to public services, health care, and socialization. As Marchetti (2020b) explains, a central feature of the SPRAR system is the direct involvement of the municipalities as leading actors: even if it has often turned out to be more formal than substantial,

inspiration by the French Front National. It achieved good electoral results in local elections also in Central and Southern Italy.

${ }^{2}$ For the main features of the Italian reception system, and in particular for the distinction between SPRAR (the best option) and CAS (the emergency solution), see the following section. 
the necessary participation of the local authorities means that no SPRAR project can be established against the municipalities' will.

The resistance by local authorities, however, and the consequent shortage of applications, has led to a lack of reception facilities, and a concentration in Southern regions. Only 35,650 places were provided (January 2019), since only 1,825 municipalities out of more than 8,000 had agreed to take part in the system. ${ }^{3}$ Furthermore, almost half of the places were located in Southern regions and Latium, where local authorities more clearly perceived the benefits of hosting asylum seekers, in terms of job creation and stimulus for the area's economic system. The richer regions, in which the possibility of refugees' employment should in theory be higher, were less willing to cooperate. As a consequence, only refugees who had received legal protection (but not all of them), unaccompanied minors, families, and frail people have been hosted in the SPRAR system. Now this possibility has been further restricted, as a consequence of the Security Package of 2018.

The government responded to this lack of reception facilities by creating a parallel system based on the Centres of Extraordinary Reception (CAS): an emergency response to a recurrent structural problem. Indeed, the huge majority of asylum seekers have been hosted in the CAS: 76 per cent at the end of 2017 (Campesi 2018, 494). In this case, the national authorities by-pass local governments by assigning to private actors (mainly, but not only, NGOs: also hotel owners and other conventional employers) the task of establishing and managing various kinds of reception facilities: often large, with large numbers of guests (sometimes, more than 100), and with uneven levels of professional competence, experience in and commitment to the integration of hosted people, relations with the local area and its services (Campesi 2018; Oxfam Italia 2017; Pinelli 2015). In some cases, the infiltration by criminal organizations has been identified, while in others unscrupulous providers have been detected, discrediting the whole system of reception. The number of asylum seekers hosted in reception facilities was 138,858 at the end of 2018 .

\footnotetext{
${ }^{3}$ https://www.sprar.it/i-numeri-dello-sprar, accessed on 20 December 2018.
} 


\section{The role of local governments in the "battleground" of asylum}

The new national policy reflects also what has happened at the local level from 2014 to 2017. We can distinguish different configurations of relations between national and local powers, and of public and non-public actors (Campomori and Ambrosini, 2020). Among them of particular importance is the opposition against the establishment of facilities for the reception of asylum seekers by local authorities.

My analysis of this issue is based on a press review of online local news. I searched the news items on the internet (years 2014-2018) using certain key-words: 'municipality'; 'rejection'; 'asylum seekers'; 'reception centre'. I conducted a content analysis on 70 articles, from twenty national and local newspapers, and I selected the most relevant cases in various regions, paying attention to the reasons given to refuse, the forms of protest, the involvement of residents, and the final results. My purpose was not to draw a complete map of the local opposition against the reception centres, but rather to highlight the main drivers of these local policies of exclusion. I define "policies of exclusion" as those measures, adopted by local authorities, which aim to ostracize migrants, to separate them, in term of rights, from the citizen component of the population by establishing specific prohibitions against them, and which set up special screening procedures or limit their access to benefits and local social policy resources. These policies form the boundaries of what is perceived by citizens as the legitimate local community, reinforcing a duality between the rightful members (the insiders, coinciding with those who identify as ethnically Italian) and outsiders, whose right to residence tends to be redefined in more limited and conditional forms. They reassure citizens about the priority of their status compared to that of outsiders, and send out the message that they are being actively defended against the "invasion" of their urban space, which they feel to be threatened (Ambrosini 2013). 
"Local policies of exclusion" are particularly significant because they can be defined as "institutionalized forms of intolerance": they are drawn up and enforced by municipalities, which are elected democratically, and which influence social life within the local communities. I also argue that since 2014 these policies have been redirected especially against asylum seekers.

Many local governments, after having rejected the invitation to manage a SPRAR project, have protested against and tried to resist the settlement of refugees on their territory through CAS centres, when the Prefects identify a suitable facility, or when a private organization responds to the public tenders for the management of such centres (Marchetti 2020b).

The opposition openly targets asylum seekers, and the public policies of reception, even if it often fosters a confusion between refugees and other immigrants. Local authorities put asylum seekers together with other foreign residents, most of whom became settled many years ago. For instance, mayors often claim that they already host a huge number of immigrants on their territory, and they cannot afford to receive other Third Country nationals.

The policy of reception through CAS centres, furthermore, favours a framing of local policies of exclusion in which mayors and municipalities protest against the imposition of refugees by national powers on local communities. A frame of contrast between overbearing central powers and peaceful local communities, which are obliged to host unknown and dangerous aliens, is recurrent.

Connected to this is the victim complex: in explaining their reasons, local authorities often have presented themselves as the "victims" of an "invasion". This frame permits the political construction of an opposition between "us", the peaceful and integrated local community, and "them", the "aliens", who are the bearers of danger, insecurity and the diminishment of welfare resources. In addition, this view promotes the idea that "we" are under attack and have the right to defend ourselves, our families, our homes and our properties (Ambrosini 2018; Lunaria 2017; Marchetti 2020b).

Historically, this kind of victim complex has triggered the persecution of ethnic and religious minorities: the majority feels itself threated by the presence of aliens, and it depicts its reaction and even the recourse to violence as a legitimate defence against this deadly danger. 
In addition, the local territory is conceived as a private property, or an extension of home. A famous slogan of the (Northern) League against immigrants declares "Masters in our own home".

An important aspect is that the protests have involved many regions and municipalities, and not only the Northern regions of Italy, where the anti-immigrant party (Northern) League has its strongholds, as occurred in the past with previous waves of local policies of exclusion. As a consequence, more than in the past, also municipalities ruled by centre-left coalitions were involved.

It can be added that, by establishing a sharp dichotomy between "us" and "them", local authorities and their supporters in some way recreate a meaning of community, reinforcing the bonds between local residents who feel and share a common threat. They find an explanation of, and an actor responsible for, their problems: their impoverishment or economic decline, feelings of insecurity, lack of prospects, are connected to the arrival of these unknown aliens. Paradoxically, fragmented local communities experience a new sense of unity in protesting against the settlement of a few asylum seekers.

The opposition of local authorities against asylum seekers can take different forms (Marchetti, 2020a). The first consists in public declarations and protests, sometimes supported by the collection of signatures among local residents. The fact that the establishment of a CAS for asylum seekers is decided by national authorities, the Prefects, representatives of the State, is a frequent reason for protest: "I do not consider correct the fact that I, the mayor, do not know who these people are, who manages them, and where they will be hosted. It is indeed not right that I am surprised at the last minute." (Mayor of Torre Boldone, province of Bergamo, March 2016). It is noteworthy that this conflict regarded eight people. Furthermore, the mayor criticized also the private owners who rented out their properties to host asylum seekers. ${ }^{4}$

The second form of opposition consists of demonstrations and other actions in the streets, with the participation of local authorities. In July 2017 a group of mayors in Sicily, near Messina, organized

\footnotetext{
${ }^{4}$ http://www.bergamonews.it/2016/03/08/otto-profughi-arrivo-torre-boldone-sindaco-mincateno/217816/
} 
a protest against the settlement of 50 asylum seekers in a hotel: they blocked the road and prevented the passage of a generator necessary to provide electricity for the hotel. They then organised a "permanent escort" in front of the hotel ${ }^{5}$.

The third form of opposition concerns official acts (ordinances, decisions of the city council), in order to block the establishment of reception centres. Some examples follow. In Saronno, Lombardy, a town with 40,000 inhabitants, in October 2016 the mayor (League) managed to block the opening of a reception centre for 32 asylum seekers. The property (a former school) belonged to a congregation of nuns and had been restructured with significant expenditure by the catholic organization Caritas Ambrosiana, following a request by the Prefect. The mayor employed legal impediments to block the transformation of the school into a reception centre, but his motivations were made clear by his declarations: "The citizens of Saronno do not want illegal immigrants, and national sovereignty belongs to the citizens of Saronno, not to the refugees (...)"6. In another interview, he declared: "I do not want African males in proximity to schools attended by our girls".

A radicalization of the fight against the establishment of reception centres for asylum seekers was expressed also by the resolution adopted in August 2017 by the mayor (League) of San Germano Vercellese, a small town in Piedmont. The resolution obtained wide coverage in the national press and in the political debate. The title of the resolution written by the mayoress and adopted by the municipal council was "Protection of the territory against invasion/immigration by populations coming from Africa and not only"8. She threatened with fines (from 150 to 5,000 euros) people who rented out properties to host asylum seekers, including non-profit and religious organizations. ${ }^{9}$

\footnotetext{
${ }^{5} \mathrm{https}: / / \mathrm{www}$. avvenire.it/attualita/pagine/migranti-sale-protesta-sindaci-nebrodi

${ }^{6} \mathrm{https}: / /$ www.ilfattoquotidiano.it/2016/10/01/migranti-sindaco-leghista-blocca-il-centro-accoglienza-delle-suore-manon-ha-fatto-i-conti-con-il-viminale/3067047/. Accessed on 29 December 2018.

${ }^{7} \mathrm{https}: / /$ milano.repubblica.it/cronaca/2017/02/23/news/clandestini_lega_condanna_discriminazione_profughi158956059/. Accessed on 29 December 2018.

${ }^{8}$ http://www.vita.it/it/article/2017/08/29/la-delibera-del-comune-che-si-tutela-dallinvasione-delle-popolazionia/144335/ . Accessed on 5 January 2019.

${ }^{9}$ http://www.vita.it/it/article/2017/08/29/la-delibera-del-comune-che-si-tutela-dallinvasione-delle-popolazionia/144335/ . Accessed on 5 January 2019.
} 
Local authorities issued an official act also in Ventimiglia, a key transit point on the border with France. Here hundreds of asylum seekers arrived, especially between 2014 and 2017, after having landed in Southern Italy with the purpose of crossing the border and applying for asylum in France. French authorities enforced the border, and asylum seekers were blocked. 'No borders' movements and other activists came to support them, providing tents and some food: an informal camp grew, a situation similar to other border zones, such as the so-called Jungle of Calais (Sandri 2018). After some months, the residents began to protest, and in August 2016, in the peak period of the tourist season, the local mayor (Democratic Party, centre-left) issued an ordinance forbidding the distribution of food outside the Red Cross camp or the Caritas facilities. ${ }^{10}$ The ordinance was issued or alleged hygienic reasons, but its meaning became clear when the public fountains near the train station were closed: the local authorities wanted to send away asylum seekers. Some activists were fined for having infringed the ban. This disposition lasted some months, provoking many protests, by Amnesty International, MSF, Caritas, among others. A public demonstration in Ventimiglia was announced. At that point, in April 2017 the mayor withdrew the ordinance. ${ }^{11}$

A fourth form of local opposition regards (apparent) spontaneous mobilizations by inhabitants, against asylum seekers. It occurred more rarely. A relevant case is that of Gorino, a hamlet with about 600 inhabitants in the province of Ferrara (region of Emilia-Romagna), with a long-standing leftist tradition. Here in October 2016 about one hundred residents blocked with barricades the three accesses to the hamlet, protesting against the settlement of 12 refugee women with eight children in a local hostel, in which five rooms had been requisitioned by the Prefect. The coach with the women was forced to go back, the Prefect had to change his decision, and the refugees were hosted in other facilities of the province. The political parties were apparently not involved at the beginning, but immediately afterwards the right wing supported the protest. The local secretary of the League spoke

\footnotetext{
${ }^{10} \mathrm{http} / /$ www.ansa.it/liguria/notizie/2016/08/12/ventimiglia-stop-a-cibo-non-autorizzato_1f8c7a35-78fa-435d-8ce1b4fc1dfdb2a7.html. Accessed on 5 January 2019.

${ }^{11}$ https://genova.repubblica.it/cronaca/2017/04/23/news/ventimiglia_revocato_il_divieto_di_distribuire_cibo_ai_migran ti-163684319/. Accessed on 5 January 2019.
} 
of "new heroes of the Resistance against the dictatorship of reception", while the mayor (Democratic Party) expressed understanding for "the fear of citizens" $"$. At the general elections of March 2018, the League achieved locally 43 per cent of votes in the Lower Chamber, the centre-right as a whole 68 per cent. $^{13}$

A fifth case comprises mobilizations openly organized or supported by far-right movements. As in other countries, the issue of asylum has been the opportunity for the radical right to find a new political space, to reach a larger public and to acquire new supporters (Castelli Gattinara 2017; as regards Germany, Bulli 2017). In Italy, an example is provided by Spinetoli, a small town in the region of Marche, with a leftist tradition. Here the mayor (Democratic Party, centre-left) in November 2017 demonstrated together with the League and CasaPound (a far-right movement explicitly connected to the Fascist heritage) against the establishment of a CAS centre, hosting 37 people. The mayor called them "an enormous number"14. About 300 people took part in a torchlight demonstration. Then CasaPound, however, distanced itself from the mayor, leaving the hall during his speech. Before the arrival of the asylum seekers, the house in which they would have resided was set on fire. The police never found the perpetrators of the crime.

In these conflicts, there are also local actors who dissent. In Saronno a network of associations, "Quattro passi di pace" ("Four steps of peace") mobilized in favour of the reception centre, but without achieving the purpose of changing the mind of the local administration. What they obtained was a verdict against the League (fined with 10,000 euros, as well as 4,000 euros of legal expenses) for having described as "clandestine" the 32 asylum seekers to be hosted, in posters that they exposed in the town. ${ }^{15}$

\footnotetext{
$12 \mathrm{http} / / /$ temi.repubblica.it/micromega-online/le-barricate-caserecce-di-gorino-e-gli-imprenditori-politici-del-razzismo/ . Accessed on 5 January 2019.

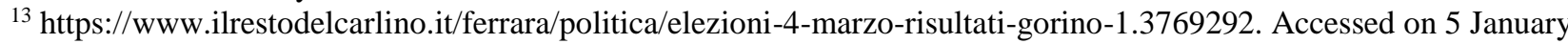
2019.

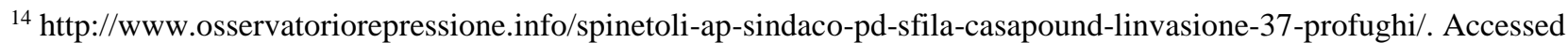
on 10 January 2019

${ }^{15} \mathrm{https}$ //milano.corriere.it/notizie/cronaca/17_febbraio_23/lega-condannata-discriminazione-profughi-non-sonoclandestini-949736fa-f9b1-11e6-9b43-a08eac6546a0.shtml. Accessed on 29 December 2019.
} 
Another relevant case occurred in Verona. Here a network ("Verona che dialoga", "Dialoguing Verona"), in which about 100 local associations take part, mobilized (July 2017) against the protest enacted by an anti-immigrant movement ("Verona ai Veronesi" "Verona to its citizens"). For many days, the protesters surrounded a reception centre in which 25 asylum seekers were hosted. They insulted and intimidated refugees and social workers, and they damaged property. Pro-immigrant associations reacted also by threatening to boycott the products of a firm that supported the protest, giving its ground to the besiegers. ${ }^{16}$

\section{On the other side of the "battleground": civil society and asylum seekers}

Local policies against asylum seekers are a case in point in a wider cartography of relations between municipalities and civil society organizations in Italy on this issue. There are also experiences of cooperation, especially when local authorities accept to manage a SPRAR project, in agreement with local NGOs. Another possibility is tolerance, when local authorities silently accept that civil society actors supply services (food, health care, language lessons, accommodation) also to people who are not taken in charge by the public institutions, whatever their legal status. Here, the role of the Catholic Church, of its institutions (for instance religious orders), services, associations, and voluntary groups is often of particular importance (Ambrosini 2016). The small protestant church is also very active in this field. Sometimes, activism by welcoming local authorities has had to face the opposition of antiimmigrant actors, especially right-wing parties, with the League at the forefront, and far right movements. Of special interest for this article, however, is the case in which local policies of exclusion are contested by active civil societies (Campomori and Ambrosini, 2020).

\footnotetext{
${ }^{16} \mathrm{http}: / /$ www.radiopopolareverona.com/old/?q=content/fermare-subito-la-violenza-razzista
} 
As in the examples cited above, in the battleground of asylum many actors from civil society mobilized, trying in various ways to combat xenophobic claims and policies of exclusion. Their activities range from the cultural level (public events, artistic and cultural activities) to inspire a different image of asylum seekers and immigrants, to political activism: some important demonstrations have taken place in large Italian cities, especially Milan in May 2017 and in March 2019.

But a crucial activity is the delivery of services. These services are both professional, as in the most contentious case of Search and Rescue in the Mediterranean, and consist in the grass-roots provision of many kinds of support: language courses, basic health services, clothing, food, and shelters for the homeless (homelessness is a condition which afflicts many rejected asylum seekers, but also recognized refugees). These services may be furnished by volunteers and are often funded by private donations along with support from other social institutions. Overall, these activities provide what Leerkes (2016) calls “secondary poor relief” and Montagna (2006) and Belloni (2016) describe more positively as "welfare from below". Another type of service is the delivery of moral support by some civil society actors, particularly faith groups (Bloch, Simona and Zetter 2014: 110).

These actors have very different identities. They range from social movements with radical stances to religious institutions, comprising trade-unions and professional associations (lawyers, doctors, journalists), NGOs and social cooperatives. We can grasp the different profiles of these actors by distinguishing four main categories.

(1) NGOs, and more widely Third Sector Organizations (TSOs), which provide services to migrants and asylum seekers mainly in professional ways, and often in agreement with public bodies. This is the case of SPRARs and CASs, which are normally managed by TSOs receiving government funds. But in other cases, as in the recent dispute on NGOs saving lives in the Mediterranean Sea, they can act against the will of governments. Also these NGOs have a local impact, as they disembark rescued people in several maritime towns of Southern Italy. 
(2) Other organised actors, including trade unions, churches and associations, which often combine practical support with political and cultural pressure. They employ professionals but also volunteers, can cooperate with public powers but also act beyond the laws, for instance by providing help to people with a dubious or irregular legal status (for a parallel to the US: Hagan, 2008)

(3) Social movements, which place the defence of immigrant rights alongside other battles against the state and the capitalist system, but now increasingly provide also concrete services to migrants and asylum seekers. Zamponi (2017) has termed them "direct social actions": "actions that do not primarily focus upon claiming something from the state or other power-holders but that instead focus upon directly transforming some specific aspects of society by means of the action itself' (Zamponi, 2017: 97).

(4) Support groups that spontaneously coalesce, especially around refugees settled in particular localities (Ellermann, 2006; Fontanari, 2017), for instance by providing help for people in transit at the railway station of Milan (Sinatti 2019), or in the border zone of Ventimiglia-Val Roja (Giliberti 2017). The German experience of the "summer of welcome" also showed a strong mobilization by private citizens, often without any associative label, or political or religious affiliation (Fleischmann 2017). Karakayali (2017) highlighted the role of "emotions" in mobilizing a relevant proportion of German citizens in favour of refugees: according to his estimates, based on several surveys, between 10 to 20 percent of the German adult population (ibid: 8).

This category of spontaneous and informal volunteers also comprises individuals who provide specific assistance with food, money and accommodation (Fontanari and Ambrosini 2018), or language lessons, integrating those provided by law in reception centres.

The rationale for this classification consists in the degree of organization: the first category (NGOs) refers to the most formal and organized actors, endowed with a professional staff. The second category (other CSOs organizations) includes various types of actors, with different levels of structuration, which mainly provide services to asylum seekers and other migrants. The third category, social movements, by definition does not employ a professional staff: social movements 
depend on militants and cannot be confused with NGOs. Finally, spontaneous volunteers are the most informal actors.

As regards the beneficiaries, asylum seekers and refugees have been at the forefront in the last decade. In fact, however, for various reasons this group cannot be easily distinguished from migrants without a legal status or in a dubious legal condition: there are for instance rejected asylum seekers, others who were rejected at the first evaluation, but are appealing against the decision, migrants who left reception centres or were expelled from them. With the exception of NGOs receiving public funds, the other actors normally do not discriminate between asylum seekers and other migrants, and are often more committed to people who are not eligible for public services.

The relations between supporters (pro-immigrant actors) and beneficiaries (asylum seekers and immigrants with irregular or dubious legal status) are generally amicable, but some problems can arise. A first typical issue is the social and cultural asymmetry: supporters have more command of the language, better knowledge of the receiving society, closer connections with other relevant actors at the local level, more legitimation to speak in the public debate. Supporters have the possibility not to share information, or to do something without telling. For asylum seekers it is very difficult to go against this (Hajer and Ambrosini, forthcoming). In other words, supporters have more power. According to Fassin (2012), this asymmetry, and the power to choose who deserves help, reproduces a "relation of inequality". Not always do asylum seekers feel empowered and enabled to speak on their own.

A second issue can be the difference in the agenda between supporters and beneficiaries. Especially when the activists are politically committed, they can advance their own objectives and priorities, while asylum seekers can cultivate different goals and values: often more mundane ones, to obtain a permit, a job, a home, and not to fight to change the society (see Nicholls 2013; Belloni 2016, for a case of conflict between Italian activists and asylum seekers in a squatted building in Rome). 


\section{The political meaning of supporting refugees}

A central issue in the analysis of the "battleground" of asylum is the relation between practical activities in favour of refugees and political commitment to producing broader changes in the legal and institutional framework. A body of literature has taken a critical stance on voluntary help disconnected from a political commitment. Karakayali (2017) has observed that volunteers, while portraying refugees as victims deprived of agency, tend to exclude references to the social or political context of suffering. In accordance with Fassin (2012), humanitarianism does not necessarily result in the claim for fundamental rights. Fassin highlights the role of emotions in fostering active solidarity with asylum seekers, while at the same time stating that several volunteers seem to avoid bringing questions of global inequality to the fore, and instead focus on issues of integration. Kleres (2017) is even more critical, claiming that "the dominant emotional regime has contributed to a relatively depoliticized form of civic action in the 'refugee crisis"'(ibid.: 138).

On studying the Greek case, Siapera (2019) compares the discourse of small, grassroots refugee support groups, which seek to re-politicise the question of refugees, with the (post)humanitarian and charity discourses of nongovernmental organisations, as well as the racist and security frames found in the mass media and policy discourse. She distinguishes three different kinds of solidarity, even if combined: human solidarity, which seeks to restore the humanity of refugees; social solidarity, which seeks to extend full social and civic rights; class or political solidarity, which repositions refugees alongside the local victims of neoliberal crisis.

In this regard, Sinatti (2019) studied the case of support to asylum seekers in transit at Milan Central Station. She drew a distinction between minimal humanitarianism which depoliticizes, focuses on mere physical needs or bare life and in effect reduces the migrants to this, and enabling humanitarianism which extends help from being focused on mere survival to the incorporation of human rights, democracy promotion and development. Therewith it questions the focus on only bare life and could in this sense be seen as political. 
In my opinion, "minimal humanitarianism" can now also be considered in some way as political, in the first place by its opponents. A new fact, in a polarized debate, is the political relevance of every activity in favour of asylum seekers and consequently the growing opposition that such activities have to face, not only in Italy. The support to asylum seekers provided by civil society actors assumes a political meaning, even when they do not declare a political commitment. Simple actions of help, like giving food (not to mention rescuing lives at sea), can be targeted by far right activists, by national governments and sometimes by local administrations, as acts of dissent, and loaded with political significance. ${ }^{17}$ Accordingly, supporters of refugees have become more conscious of the symbolic meaning of the help they give, also in simple and mundane ways. As Schmid, Evers and Mildenberger show in the case of Germany, "what is to be done and changed in the name of 'good' and 'human' attitudes has become highly disputed and therefore an increasingly 'politicized' topic" $(2019,168)$ In this vein Sandri (2018) talks of "volunteer humanitarianism" of "grassroots organizations" at the so-called Jungle of Calais. She emphasizes the political meaning of this offer of services: "it stands as a symbol against the strict and violent policies of migration across Europe" (ibid.: 66). Even if these grassroots organisations were not initially motivated by political considerations or connected with political activism, but mobilised by humanitarian concerns, they went beyond the "neoliberal governance" of borders, contesting States and border regimes. Thus, this form of humanitarianism "cannot be interpreted simply as an expression of the neoliberal project." (ibid.: 76). Furthermore, as Zamponi (2017) describes in his discussion of direct social actions, help to asylum seekers can begin as apolitical action, yet can over time foster the politicization of the supporters being confronted directly with the situation, and become a vehicle for the expression of legitimate political claims since supporters gain 'expertise' through their experience from the actions. Fleischmann (2017) in turn, in her study on help to refugees in Southern Germany, shows how volunteers, while ostensibly defining

\footnotetext{
${ }^{17}$ At the time of writing (beginning of July 2019), the leading item of Italian news was the conflict between the Italian government and the young captain of the ship Sea Watch 3, the German Carola Rackete. What she defined as an act of humanity was considered by the government a political attack on the national sovereignty.
} 
their activity "apolitical", in fact act at a political level in three ways: as "covert activists", when they strategically avoid revealing the political meaning of their action; as "change agents", when they try to influence the local society by promoting more acceptance of ethnic diversity; as "political dissenters", when they protest against political decisions hostile to refugees. In sum, "the 'apolitical' can indeed be highly political", as "new meanings of political action stem from the manifold acts of volunteering for refugees." (ibid., 55).

\section{Conclusions. The local dispute on asylum}

Immigration policies are one of the most controversial issues in the political debate at the national and international level. Asylum, in particular since the Arab springs of 2011 has become particularly important as the typical case of unwanted migration, and the target of many xenophobic stances. A "rhetoric of abuse" is increasingly adopted in its regard (Schuster 2009), a systematic suspicion that refugees exploit the humanitarian protection to enter and settle in richer countries, even if 84 per cent of international refugees are actually hosted in poorer countries (UNHCR 2019).

This dispute has a local expression that is particularly relevant in Italy. In general the municipal level is crucial for the acceptance and the social "integration" of refugees, but the controversy on the reception of asylum seekers has highlighted the horizontal dimension of migration governance. By this term (horizontal dimension) I mean an arena in which not only public institutions and political actors are involved, but also non-public actors (Scholten et al. 2018), and often ones non-political in conventional terms. They engage in the public debate, trying to create a better climate for the acceptance of migrants and refugees, but also delivering goods and services to respond to their practical needs. I have tried to advance understanding of the pro-refugee civil society by distinguishing four type of actors, according to their level of formal organization: NGOs, other civil society organizations (churches, trade-unions, associations...), social movements, spontaneous mobilizations of common citizens. 
On the other side, far-right movements and xenophobic claims support policies of exclusion. I placed this conflict among diverse actors and views of asylum under the heading of 'battleground'.

This article has contributed to the literature on asylum policies in Europe in three ways. The first contribution regards the introduction of the concept of "battleground" to frame conflicts and alliances on migration and asylum policies between different actors at the local level, where beyond public players, political parties and migrants, several civil society actors are involved: a dynamics of the horizontal dimension of the multilevel governance of migration. The second aspect concerns the discussion of "local policies of exclusion" against immigrants, in terms of how these policies have targeted asylum seekers and how at the same time they have been contrasted by pro-immigrant actors. The third input refers to a typology of these pro-immigrant actors, structured in four classes, namely NGOs, and more widely Third Sector Organizations (TSOs); other organised actors; social movements; support groups that spontaneously coalesce.

Directions for future research should consist primarily in an analysis of urban policies of asylum, considering not only "sanctuary cities" or "cities of refuge", but also cities which reject people in need of humanitarian protection. Second, it is necessary to gain better understanding of the mobile dynamics of the local "battleground", and in particular the conflict between alternative views and mobilizations. Here more detailed comparison between the EU and North America would be instructive. Third, examination of the social and cultural backgrounds of pro-immigrant and antiimmigrant actors is desirable, together with study of how their practical commitment involves new political views, alliances, and other forms of activism. Fourth, the role of asylum seekers and refugees, and of other migrants and their movements, should be considered and compared with those of native pro-immigrant actors. If immigration and asylum continue to occupy a central place in the political debate, a deeper understanding of the construction of the governance of the issue will become even more necessary. 


\section{References}

Agier, M. 2008. Gérer les indésirables. Des camps de réfugiés au gouvernement humanitaire. Paris: Flammarion

Alcantara, C., and J. Nelles. 2014. Indigenous Peoples and the State in Settler Societies: Toward a More Robust Definition of Multilevel Governance. Publius: The Journal of Federalism 44 (1): 183204.

Ambrosini, M. 2013. We are against a multi-ethnic society': policies of exclusion at the urban level in Italy. Ethnic and Racial Studies 36 (1): 136-155

Ambrosini, M. 2016. Protected but Separate: International Immigrants in the Italian Catholic

Church. In Migration, Transnationalism and Catholicism, edited by D. Pasura and M. Bivand Erdal, 317-335. Cham: Palgrave.

Ambrosini, M. 2018. Irregular immigration in Southern Europe. Actors, Dynamics and Governance. Cham: Palgrave.

Ansems de Vries, L., and E. Guild 2019. Seeking refuge in Europe: spaces of transit and the violence of migration management. Journal of Ethnic and Migration Studies 45 (12): 2156-2166.

Baldwin-Edwards, M., B. K. Blitz and H. Crawley 2019. The politics of evidence-based policy in Europe's 'migration crisis'. Journal of Ethnic and Migration Studies 45 (12): 2139-2155.

Bauder, H. 2017. Sanctuary Cities: Policies and Practices in International Perspective. International Migration 55 (2): 174-187.

Belloni, M. 2016. Learning How to Squat: Cooperation and Conflict between Refugees and Natives in Rome. Journal of Refugee Studies 29 (4): 506-527.

Bloch, A., N. Sigona, and R. Zetter. 2014. Sans papiers. The Social and Economic Lives of Young Undocumented Migrants. London : Pluto Press. 
Bruno, M. (2016). Media Representations of Immigrants in Italy: Framing Real and Symbolic Borders. REMHU - Rev. Interdiscip. Mobil. Hum, 24 (46), pp.45-58

Bulli, G. 2017. Anti-islamism and beyond. Pegida. Mondi migranti 11 (3): 119-135.

Campesi, G. 2018. Between containment, confinement and dispersal: The evolution of the Italian reception system before and after the 'refugee crisis'. Journal of Modern Italian Studies, 23: 490506.

Campomori, F., and M. Ambrosini. 2020. Beyond multilevel governance: the implementation of asylum seekers' reception in Italy as a battleground. Comparative migration studies (forthcoming) Caselli, M. 2019. “Let Us Help Them at Home”: Policies and Misunderstandings on Migrant Flows Across the Mediterranean Border. Journal of International Migration and Integration. Published online in early view. Accessed on $30^{\text {th }}$ August 2019.

Castelli Gattinara, P. 2017. Mobilizing against 'the invasion': Far right protest and the 'refugee crisis' in Italy. Mondi Migranti 11 (2): 75-95.

Chand, D. E., and W. D. Schreckhise. 2014. Secure Communities and Community Values: Local Context and Discretionary Immigration Law Enforcement. Journal of Ethnic and Migration Studies 41 (10): 1621-1643.

CLIP Network (Cities for local integration policy), 2010. Intercultural policies in European cities. Dublin: European Foundation for the Improvement of Living and Working Conditions.

D’Angelo, A. 2019. Italy: the 'illegality factory'? Theory and practice of refugees' reception in Sicily. Journal of Ethnic and Migration Studies, 45 (12): 2213-2226.

Dimitriadis, I. 2019. The construction of the crisis-invasion discourse by different stakeholders in Italy, Working Paper, Available at: https://www.magyc.uliege.be/wp-content/uploads/2019/07/WP3-D.3.3-The-construction-of-thecrisis-invasion-discourse-Unimi.pdf. Accessed on 7 February 2020. 
Ellermann, A. 2006. Street-Level Democracy: How Immigration Bureaucrats Manage Public Opposition. West European Politics 29 (2): 293-309.

European Commission 2015. Communication from the Commission to the European Parliament, the Council, the European Economic and Social Committee and the Committee of the Regions. A European Agenda on Migration. COM (2015) 240. Brussels.

Faist, T. 2002. Extension du domaine de la lutte: international migration and security before and after September 11, 2001. International Migration Review 36 (1): 7-14.

Fassin, D. 2012. Humanitarian reason: A moral history of the present. Berkeley: University of California Press.

Ferrer-Gallardo, X. and Albet-Mas, A. 2016. EU-Limboscapes: Ceuta and the proliferation of migrant detention spaces across the European Union. European Urban and Regional Studies 23 (3) $527-$ 530.

Fleischmann, L. 2017. The Politics of Helping Refugees. Emerging Meanings of Political Action around the German 'Summer of Welcome'. Mondi migranti 11 (3): 53-73.

Fontanari, E. 2017. Subjectivities en transit. Fragmented everyday lives of temporary refugees (im)mobile between European borders. London: Routledge.

Fontanari E., and M. Ambrosini. 2018. Into the Interstices: Everyday Practices of Refugees and Their Supporters in Europe's Migration 'Crisis'. Sociology 52 (3): 587-603.

Fontanari E. and G. Borri. 2017. Introduction. Civil society on the edge: actions in support and against refugees in Italy and Germany. Mondi Migranti 11 (3): 23-51.

Gammeltoft-Hansen, T. and N. Nyberg Sørensen, eds. 2013. The Migration Industry and the Commercialization of International Migration. London: Routledge

Guiraudon, V., and G. Lahav. 2000. The State Sovereignty Debate Revisited: The Case of Migration Control. Comparative Political Studies 33 (2): 163-195. 
Gilbert, L. 2009. Immigration as Local Politics: Re-Bordering Immigration and Multiculturalism through Deterrence and Incapacitation. International Journal for Urban and Regional Research 33 (1): $26-42$.

Giliberti, L. 2017. La criminalizzazione della solidarietà ai migranti in Val Roja: note dal campo. Mondi migranti 11 (3): 161-181.

Hagan J. 2008. Migration Miracle. Faith, Hope and Meaning on the Undocumented Journey. Cambridge (Mass.); Harvard University Press.

Hajer, M. and M. Ambrosini (manuscript under review). Who helps irregular migrants? Supporters of irregular migrants in Amsterdam (the Netherlands) and Turin (Italy).

Hillman, F. 2019. Cities becoming players in the field of migration, Topos magazine (forthcoming) Karakayali, S. 2017. Feeling the Scope of Solidarity: The Role of Emotions for Volunteers Supporting Refugees in Germany. Social Inclusion 5 (3): 7-16

Kleres, J. 2017. Feeling the refugee crisis: Civic mobilizations in Germany. Mondi Migranti, 11 (3): pp. 137-160.

Lebuhn, H. 2013. Local border practices and urban citizenship in Europe. City: analysis of urban trends, culture, theory, policy, action 17 (1): 37-51.

Leerkes, A. 2016. Back to the poorhouse? Social protection and social control of unauthorised immigrants in the shadow of the welfare state. Journal of European Social Policy 26 (2): 140-154 Lunaria (ed.), 2017, Accoglienza. La propaganda e le proteste del rifiuto, le scelte istituzionali sbagliate, $\quad$ Focus $\quad$ N.1/2017, $\quad$ March, $\quad$ https://www.lunaria.org/wpcontent/uploads/2017/03/0FOCUS1_DEFINITIVO_13marzo.pdf. Downloaded on 7 February 2020. Mankou, B. A. 2013. Calais, une prison ouverte pour les migrants. Hommes \& Migrations, 47 (4): 35-39.

Mantovan, C. and E. Ostanel 2015. Quartieri contesi. Convivenza, conflitti e governance nelle zone Stazione di Padova e Mestre. Milano: FrancoAngeli 
Marchetti C. 2020a. Cities of exclusion: Are local authorities refusing asylum seekers? In Migration, Borders and Citizenship, edited by M. Ambrosini, M. Cinalli, and D. Jacobson D., 237-264. Cham: Palgrave.

Marchetti, C. 2020b. (Un)Deserving refugees. Contested access to the "community of value" in Italy. In Europe and the refugee response. A crisis of values?, edited by E. M. Gozdziak, I. Main and B. Suter, 236-252 . London: Routledge.

Montagna, N. 2006. The de-commodification of urban space and the occupied social centres in Italy. City, 10 (3), 295-304.

Nicholls, W. J. 2013. Fragmenting citizenship: dynamics of cooperation and conflict in France's immigrant rights movement. Ethnic and Racial Studies 36 (4): 611-631

Oomen, B., M. Davis, and M. Grigolo 2016. Global Urban Justice: The Rise of Human Rights Cities. Cambridge: Cambridge University Press.

Oomen, B. and E. Leenders 2020. Symbolic laws, street-level actors: Everyday bordering in Dutch Participation Declaration workshops. In Migration, Borders and Citizenship, edited by M. Ambrosini, M. Cinalli, and D. Jacobson D., 265-294. Cham: Palgrave.

OXFAM Italia. 2017. La lotteria Italia dell'accoglienza. Il sistema dell'emergenza permanente. Rome: Oxfam.

Penninx, R. et al. eds. 2004. Citizenship in European Cities. Immigrants, Local Policies and Integration Policies. Aldershot: Ashgate

Pinelli B. 2015. Politiche, persone, immagini. In Dopo l'approdo. Un racconto per immagini e parole sui richiedenti asilo in Italia, edited by B.Pinelli and L. Ciabarri, pp. 49-85. Firenze: Ed.it.

Rumford, C. 2006. Theorizing Borders. European Journal of Social Theory 9 (2): 155-169. Sandri, E. 2018. 'Volunteer Humanitarianism': volunteers and humanitarian aid in the Jungle refugee camp of Calais. Journal of Ethnic and Migration Studies 44 (1): 65-80 
Schmid V., A. Evers, and G. Mildenberger 2019. More or Less Political: Findings on a Central Feature of Local Engagement for Refugees in Germany. Social Inclusion 7 (2): 165-175

Scholten, P. W. A, G. B. M. Engbersen, M. M. A. C. van Ostaijen, and E. Snel. 2018. Multilevel governance from below: how Dutch cities respond to intra-EU mobility. Journal of Ethnic and Migration Studies 44 (12): 2011-2033.

Schuster, L. 2009. Dublino II ed Eurodac: esame delle conseguenze (in)attese. In Mondi Migranti, 3 (3): 37-56.

Sciortino, G. 2019. L'equilibrio impossibile: rifugiati e stati democratici. In Arel La Rivista 2: 4550.

Semprebon, M. 2011. Phone centres and the struggle for public space in Italy: between revanchist policies and practices of resistance. Journal of Urbanism: International Research on Placemaking and Urban Sustainability 4 (3): 223-237.

Siapera, E. 2019. Refugee solidarity in Europe: Shifting the discourse. European Journal of Cultural Studies. Published online in early view. Accessed on 25 June 2019.

Sinatti, G. 2019. Humanitarianism as politics: Civil support initiatives for migrants in Milan's hub. Social Inclusion, 7 (2). Published on line in early view. Accessed on 25 of June 2019.

Varsanyi, M. W. 2008, Immigration Policing Through the Backdoor: City Ordinances, the "right to the City," and the Exclusion of Undocumented Day Laborers. Urban Geography 29 (1): 29-52. Zamponi, L., 2017. Practices of Solidarity: Direct Social Action, Politicisation and Refugee Solidarity Activism in Italy. Mondi Migranti 11 (3). 97-117. 